\title{
Impact of front line demonstration of chickpea (JG 63) in Chhatarpur district of Madhya Pradesh, India
}

\author{
Arpita Shrivastava*, Smita Singh ${ }^{1}$, Veena Pani Shrivastava ${ }^{2}$ and Uttam Kumar Tripathi ${ }^{3}$ \\ Krishi Vigyan Kendra, Katni (M.P.) India \\ (Email: arpita.jnkvv@gmail.com)
}

\begin{abstract}
The present investigation was carried out at the adopted villages of Krishi Vigyan Kendra, Chhatarpur during 2017-18 to demonstrate the improved variety JG 63 with the scientific package and practices to improve the production of chickpea. The treatment comprised of scientific package of practices (Improved variety JG $63+$ seed treatment with Carbendazim $3 \mathrm{~g} / \mathrm{kg}$ of seed and seed inoculation with Rhizobium and PSB culture each @ $10 \mathrm{~g} / \mathrm{kg}$ of seed + soil test value based fertilizer application + line sowing + adoption of IPM technique). The demonstration plot exhibited higher yield as compared to farmers plot. An average yield of chickpea in the demonstrated plot was $18.74 \mathrm{q} / \mathrm{ha}$ as compare to farmers practices $14.16 \mathrm{q} / \mathrm{ha}$ in the three years of pooled data. The improved technology gives the higher return with the high benefit cost ratio as farmer's practices. The observed extension gap, technology gap and technology index were $4.58 \mathrm{q} / \mathrm{ha}, 1.26 \mathrm{q} / \mathrm{ha}$ and $6.30 \%$, respectively. The improved variety with scientific package of practices and technical guidance contributed to increase production of chickpea and profitability of the farmers of the district.
\end{abstract}

Key Words : BC ratio, Chickpea, FLD, Technology gap

View Point Article : Shrivastava, Arpita, Singh, Smita, Shrivastava, Veena Pani and Tripathi, Uttam Kumar (2021). Impact of front line demonstration of chickpea (JG 63) in Chhatarpur district of Madhya Pradesh, India. Internat. J. agric. Sci., 17 (AAEBSSD) : $307-310$, DOI:10.15740/HAS/IJAS/17-AAEBSSD/307-310. Copyright@2021: Hind Agri-Horticultural Society.

Article History : Received : 01.08.2021; Accepted : 04.08.2021

\section{INTRODUCTION}

Pulses are the important part of human diet as they are the chief source of protein of majority of the population of India. Pulses contribute $11 \%$ of the total intake of the proteins in India (Reddy, 2010). Keeping the cheapest source of protein, it is important to increase pulse production to increased balances diet among the socially and economically backward classes (Dhakad et al., 2018). Among all the pulses chickpea is the second most important food legume after pigeonpea. India is the largest producer of the chickpea accounting $75 \%$ of the world population (Dudhade et al., 2009). But still the productivity was low due to lack of adoption of improved production technologies. Through the much progress has been made in the field if agricultural research and education, but the benefits of these developments could not be realized by the farming community because of low adoption of the technologies at the farmers level

\footnotetext{
*Author for correspondence:

${ }^{1}$ Krishi Vigyan Kendra, Rewa (M.P.) India

${ }^{2}$ Krishi Vigyan Kendra, Chhatarpur (M.P.) India

${ }^{3}$ Krishi Vigyan Kendra, Satna (M.P.) India
} 
Arpita Shrivastava, Smita Singh, Veena Pani Shrivastava and Uttam Kumar Tripathi

(Dhakad et al., 2018). In the light of above, Krishi Vigyan Kendra, Chhatarpur organized the Front Line Demonstration programme on improved production technologies of chickpea. The FLD are one of the systematic methods to test the potential of the technology at the farm by acquiring the participating farmers and its adoption by non participating farmers (Singh et al., 2017). The FLD are under the close supervision of scientist of the KVK. Therefore, this investigation was carried out to increase the per capita availability of pulse and popularization of improved production technology amongst the farming community of the area.

\section{Material AND Methods}

The front line demonstrations were conducted by Krishi Vigyan Kendra, Chhatarpur during Rabi season in 2017-18. The demonstration was conducted in farmer's field of Sunwaha village in Buxwaha block of Chhatarpur district of Madhya Pradesh in 0.4 ha area under each demonstration. In general, the soil of the district was alluvial soil in texture with $\mathrm{pH}$ ranges in between 6.8 to 7.2. The treatment comprised of scientific package of practices (Improved variety JG $63+$ seed treatment with
Carbendazim $3 \mathrm{~g} / \mathrm{kg}$ of seed and seed inoculation with Rhizobium and PSB culture each @ $10 \mathrm{~g} / \mathrm{kg}$ of seed + soil test value based fertilizer application + line sowing + adoption of IPM technique). The sowing of chickpea was done in first week of November with a spacing of $30 \times 10 \mathrm{~cm}$. the seed rate was $75 \mathrm{~kg} / \mathrm{ha}$. Integrated crop management practices were applied for the proper growth of the plant as per the recommendation of scientist. The crop was harvested at perfect maturity stage and data were recorded in addition to economic analysis. The extension gap, technology gap and technology Index, Benefit cost ratio (BCR) were worked out as per Samui et al. (2000), as given below.

Extension gap $=$ Demonstration plot yield - farmers practice plot yield

Technology Gap $=$ Potential yield- Demonstrated yield

Technology index $(\%)=\frac{\text { Technology gap }}{\text { Potential yield }} \times 100$

\section{Results AND Discussion}

The present investigation carried out in 2017-18 at farmers field under front line demonstration programme. The result summarized in the Table 1-3.

\begin{tabular}{|c|c|c|c|c|}
\hline Sr. No. & Technology & Improved practice & Farmers practice & Technology gap \\
\hline 1. & Variety & JG 63 & Local variety/ Asha & Full gap \\
\hline 2. & Seed rate & $75 \mathrm{~kg} / \mathrm{ha}$ & $90-100 \mathrm{~kg} / \mathrm{ha}$ & Full gap \\
\hline 3. & Sowing method & Line s owing & Broadcasting & Full gap \\
\hline 4. & Seed treatment & $\begin{array}{c}\text { Carbendazim } 3 \mathrm{~g} / \mathrm{kg} \text { of seed and Rhizobium } \\
\text { and PSB culture each @ } 10 \mathrm{~g} / \mathrm{kg} \text { of seed }\end{array}$ & Not followed & Full gap \\
\hline 5. & Fertilizer dose & STV based fertilizer application & Non judicious use of fertilizers & Partial gap \\
\hline 6. & Plant protection measures & IPM & Indiscriminate use of pesticides & Partial gap \\
\hline
\end{tabular}

\begin{tabular}{llcc}
\hline \multicolumn{4}{l}{ Table 2: Productivity and economics in chickpea (JG 63) under front line demonstration } \\
\hline Sr. No. & Particulars & Improved practice & Farmers practice \\
\hline 1. & Average yield (q/ha) & 18.74 & 14.16 \\
2. & Cost of cultivation (Rs./ha) & 19000 & 17524 \\
3. & Gross return (Rs./ha) & 47520 & 35464 \\
4. & Net return (Rs./ha) & 28520 & 17940 \\
5. & B:C ratio & 2.50 & 2.02 \\
\hline
\end{tabular}

\begin{tabular}{llc}
\hline \multicolumn{2}{l}{ Table 3: Technology gap, extension gap and technology index in chickpea (JG 63) under front line demonstration } & \\
\hline Sr. No. & Particulars & Result \\
\hline 1. & Extens ion gap (q/ha) & 4.58 \\
2. & Technology gap (q/ha) & 1.26 \\
3. & Technology in dex (\%) & 6.30 \\
\hline
\end{tabular}




\section{Gap in adoption:}

In the present investigation, farming community was motivated to adopt the scientific package of practices. Full gap was observed in case of use of improved variety, seed rate, sowing method and seed treatment, while partial gap was observed in case of fertilizer dose and plant protection measures (Table 1). Farmers were using old age or unidentified varieties instead of improved high yielding varieties. The main reason of this is lack of awareness and unavailability of seed. Farming community unaware about the seed treatment and seed inoculation. These practices increase the chance of disease incidence. They also followed the broadcast method of sowing against the line sowing and this leads to higher seed rate against the recommended. Farmers unaware about the soil testing and use fertilizer non judiciously. This emphasized of need to educate the farmers for adoption of new scientific package of practice, which include high yielding variety JG 63+ seed treatment with Carbendazim (a) $3 \mathrm{~g} / \mathrm{kg}$ of seed and seed inoculation with Rhizobium and PSB culture each@10 g/ kg of seed + line sowing + STV based fertilizer application + need based plant protection measures (Prophanophos@1.2 liter/ha at pod formation stage for control of pod borer). Front line demonstration programme plays a major role to disseminate the scientific technology to increase the yield potential at farmer's level.

\section{Yield potential :}

During the study, an average yield of chickpea in the demonstrated plot was $18.74 \mathrm{q} / \mathrm{ha}$ as compare to farmers practices $14.16 \mathrm{q} /$ ha (Table 2 ). The percentage of increase in yield over the farmer's practices was $24.43 \%$. This result clearly indicated that higher yield in the demonstration plot observed due to adoption of scientific package of practices over the farmer's practice. Similar finding were also reported by Amule et al. (2016) and Raj et al. (2013).

\section{Extension gap analysis:}

The extension gap in the demonstrated yield over the farmers yield were 4.58 (Table 2). This indicate to organize various extension activity i.e. demonstration, training, meeting etc. for encourage the farming community to adopt the scientific package of practice. This helps to revert the trend of wide extension gap. More and more use of latest production technology with high yielding varieties will subsequently change this alarming trend of galloping extension gap (Dhakad et al., 2018). The new technology eventually leads to the farmers to discontinue the old technology (Hiremath and Nagraju, 2010).

\section{Technology gap analysis:}

The technology gap in the demonstrated yield over the potential yield was 1.26 . The technology gap may be attributed to the dissimilarity in the soil fertility status, agricultural practices and local climatic conditiona (Mukharjee 2003; Dhakad et al., 2018).

\section{Technology index:}

The technology index shows the feasibility of demonstrated technology at farmer's field. The observed technology index of the study was $6.30 \%$. The lower the value of technology index shows the more feasibility of the technology (Jeengar et al., 2006 and Singh et al., 2007). This will accelerate the adoption of demonstrated technical intervention to increase the yield performance (Dhakad et al., 2018).

\section{Economic analysis:}

The cost of input and output prevailed during the demonstration was used for interpretation of cost of cultivation, gross return, net return and benefit cost ratio (Table 3). The cost of cultivation of improved technology adopt in the demonstration plot was higher than the farmers plot. But it also gave the higher net return of Rs. 28520 /ha as compared to farmers practices of Rs. 17940 / ha. This may be due to higher yield observed in the demonstrated plot due to adoption of scientific package of practice. The benefit cost ratio of chickpea under improved technology was 2.50 as compared to 2.02 in farmers plot. This finding was in consonance with finding of Mokidue et al., 2011; Raj et al., 2013; Amule et al., 2016 and Dhakad et al., 2018.

\section{REFERENCES}

Amule, R., Raut, R. L., Bisen, S., Bisen, U. and Dhurvey, S. R. (2016). Impact study of front line demonstration on productivity of pigeonpea (Cajanus cajan) and chickpea (Cicer arietinum) at farmers field in chattisgarh plain of Madhya Pradesh. Inter. J. of Agril. Sci., 8 (53): 2758-2760.

Dhakad, S.S., Asati, K. P., Chauhan, S. S., Badaya, A. K., Kirar, K.S. and Ambawatia, G.R. (2018). Impact of front line demonstration on the yield and economics of chickpea (Cicer arietinum L.) in tribal area of Madhya Pradesh, India. Inter J. 
Arpita Shrivastava, Smita Singh, Veena Pani Shrivastava and Uttam Kumar Tripathi

Curr. Microbiol. App. Sci., 7 (05) : 3662-3666.

Dudhade, D. D., Deshmukh, G. P., Harer, P. N. and Patil, J. V. (2009). Impact of front line demonstration of chickpea in Maharastra. Leg. Res., 32(3): 206-208.

Hiremath, S.M. and Nagaraju, M. V. (2010). Evaluation of on-farm front line demonstrations on the yield of chilli. Karnataka J. Agric. Sci., 23 (2): 341-342.

Jeengar, K. L., Panwar, P. and Pareek, O.P. (2006). Front line demonstration on maize in Bhilwada district of Rajasthan. Current Agriculture, 30 (1/2):115-116.

Mokidue, I., Mohanty, A. K. and Sanjay, K. (2011). Correlating growth yield and adoption of Urdbean technology. Indian J. Extn.Edu., 11 (2): 20-24.

Mukherjee, N. (2003). Participatory, learning and action. Concept, Publishing Company, New Delhi, pp.63-65.

Raj, A. D., Yadav, V. and Rathod, J.H. (2013). Impact of front line demonstration on the yield of pulses. Int. J. Sci. Res. Public., 3 (9) : 2250-2254

Reddy, A. A. (2010). Regional disparities in food habits and nutritional intake in Andhara Pradesh, India. Regional \& Sectoral Economic Studies, 1-10.

Samui, S.K., Maitra, S., Roy, D.K., Mandal, A.K. and Saha, D. (2000). Evaluation of front line demonstration on groundnut. J. Indian Soc. Coastal Agril. Res., 18(2): 180-183.

Singh, J., Hundak, R. K. and Dhillon, B.S.(2017). Comparison for yield potential of chickpea in front line demonstration and farmer practices in Amritsar district of Punjab. Curr. Agril. Res. J., 5 (2) : 239-243.

Singh, S.N., Singh, V.K., Singh, R.K. and Singh Rakesh, K. (2007). Evaluation of on-farm frontline demonstrations on the yield of mustard in Central Plain Zone of Uttar Pradesh. Indian Res. J. Ext. Edu., 7(2\&3):79-81.

$16^{\text {thear }}$

$\star \star \star \star \star$ of Excellence $\star \star \star \star \star$ 